\title{
The Case for Healthy U.S.-China Agricultural Trade Relations despite Deglobalization Pressures
}

\author{
Wendong Zhang \\ Working Paper 20-WP 611 \\ October 2020 \\ Center for Agricultural and Rural Development \\ lowa State University \\ Ames, lowa 50011-1070 \\ www.card.iastate.edu
}

Wendong Zhang is Assistant Professor, Department of Economics, lowa State University, Ames, IA 50011. E-mail: wdzhang@iastate.edu.

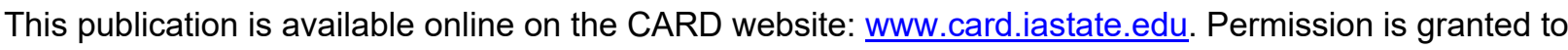
reproduce this information with appropriate attribution to the author and the Center for Agricultural and Rural Development, lowa State University, Ames, lowa 50011-1070.

For questions or comments about the contents of this paper, contact Wendong Zhang, wdzhang@iastate.edu.

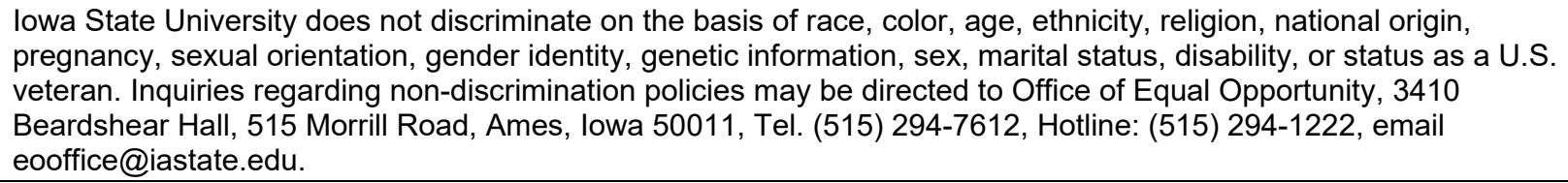




\title{
The Case for Healthy U.S.-China Agricultural Trade Relations Despite Deglobalization Pressures*
}

\author{
Wendong Zhang ${ }^{\dagger}$
}

\begin{abstract}
The COVID-19 pandemic is crippling the global economy and heightening distrust and political disagreements among major countries. Furthermore, ongoing deglobalization efforts taken by firms and countries are fueling the rise of economic nationalism. A prime example is the possible decoupling of U.S.-China economic and trade relations, which the ongoing trade war has already significantly disrupted. This paper analyzes the impacts of COVID-19 on U.S. agricultural exports to China, especially the added delays and uncertainty on China's food imports meeting the U.S.-China phase one trade deal target. I present the views of U.S. farmers and the general public toward China and argue that healthy U.S.-China agricultural trade relations are not only critical for both countries but welcomed by U.S. farmers. I also discuss the possible rise in non-tariff barriers following the pandemic as well as trade policies that are increasingly intertwined with political tensions. Finally, I discuss how the U.S.-China phase one trade deal could possibly lead to a more balanced bilateral agricultural trade portfolio with greater share of protein and retail food products.
\end{abstract}

Keywords: Agricultural Trade; Trade War; COVID-19; Globalization; Supply Chain; Agricultural Export; Trade Policy

JEL Codes: Q17, Q18, F13, F60, F52

\section{Forthcoming at Applied Economic Perspectives and Policy}

\footnotetext{
*The author gratefully acknowledges support from the USDA National Institute of Food and Agriculture Hatch Project 101,030 and grant 2019-67023-29414. The author also thanks Chad Hart, Mike Duffy, Kelvin Leibold, Xi He, Minghao Li, and Nate Cook for feedback on an earlier draft.

${ }^{\dagger}$ Assistant Professor, Department of Economics and Center for Agricultural and Rural Development (CARD), Iowa State University, wdzhang@iastate.edu
} 


\title{
The Case for Healthy U.S.-China Agricultural Trade Relations Despite Deglobalization Pressures*
}

\begin{abstract}
The COVID-19 pandemic is crippling the global economy and heightening distrust and political disagreements among major countries. Furthermore, ongoing deglobalization efforts taken by firms and countries are fueling the rise of economic nationalism. A prime example is the possible decoupling of U.S.-China economic and trade relations, which the ongoing trade war has already significantly disrupted. This paper analyzes the impacts of COVID-19 on U.S. agricultural exports to China, especially the added delays and uncertainty on China's food imports meeting the U.S.-China phase one trade deal target. I present the views of U.S. farmers and the general public toward China and argue that healthy U.S.-China agricultural trade relations are not only critical for both countries but welcomed by U.S. farmers. I also discuss the possible rise in non-tariff barriers following the pandemic as well as trade policies that are increasingly intertwined with political tensions. Finally, I discuss how the U.S.-China phase one trade deal could possibly lead to a more balanced bilateral agricultural trade portfolio with greater share of protein and retail food products.
\end{abstract}

Keywords: Agricultural Trade; Trade War; COVID-19; Globalization; Supply Chain; Agricultural Export; Trade Policy

JEL Codes: Q17, Q18, F13, F60, F52 
In this time of crisis, we face two particularly important choices. The first is between totalitarian surveillance and citizen empowerment. The second is between nationalist isolation and global solidarity.

- Harari [2020], the Financial Times 'The World after Coronavirus.'

\section{Introduction}

The novel coronavirus (2019-nCoV or COVID-19) has shocked the world's economies International Monetary Fund, 2020] and imposed significant uncertainty and pressure on the already-stressed U.S. agricultural sector. According to the USDA (U.S. Department of Agriculture) Economic Research Service, projected inflation-adjusted 2020 net farm income is still 25\% below its 2013 peak [USDA Economic Research Service, 2020]. The COVID-19 pandemic has also drastically lowered prices for major agricultural commodities, especially livestock and ethanol products Lusk and Anderson, 2020], and farm loan delinquencies and farm bankruptcies are projected to further increase [Newton, 2020]. In early 2020, the new U.S.-China phase one trade deal became a major hope among U.S. farmers and rural communities for the expected agricultural export surges it promised [Bown, 2020, Zhang, 2020]. However, the global spread of COVID-19 has significantly delayed the promised purchases of agricultural products, which will make it even more difficult for China to meet the goal of purchasing $\$ 12.5$ billion more in U.S. farm products than in 2017 (the baseline year for phase one trade goals) XXiong and Zhang, 2020, He et al., 2020a]. The COVID-19 pandemic is also triggering the use of trade barriers, causing nations and firms to undertake efforts to decouple supply chains Sheldon and Grant, 2020, Glauber, 2020, Martin and Glauber, 2020], which increases the signs for more problematic U.S.-China relations Devlin et al., 2020]. Furthermore, the trade war and current pandemic are generating strategic risk management incentives for firms to reduce workforce health risks through increased automation, and to reduce their political risks by diversifying trade networks and accounting for the risk 
of political disruptions in supply chains. At this critical juncture of heightened uncertainties and deglobalization pressures exacerbated by COVID-19, it is crucial to examine the barriers and opportunities for U.S.-China agricultural trade relations - relations that are critical for easing U.S. farmers' current financial stress and to the future of U.S. agricultural exports.

The COVID-19 pandemic added significant uncertainty and challenges to China meeting the agricultural purchases required in the phase one deal He et al., 2020a, especially during first few months of 2020. The political debates regarding the origin and optimal control strategies of the virus also led to a further deterioration of the general U.S. public's view of China Devlin et al. 2020]. China started strategically diversifying away from the United States long before the start of the trade war Zhang, 2019 and the United States has increasingly embraced an "economic dis-integration" view toward multilateral trade systems Chow et al., 2019], which generates more concerns regarding the future of U.S.-China agricultural trade relations. The flight-to-safety sentiment among investors led to a strengthening of the U.S. dollar, which, coupled with a depreciated Brazil real, gave China incentive to purchase soybeans from Brazil rather than the United States. Despite these mounting deglobalization pressures, recent surveys of U.S. farmers clearly show that they remain optimistic about the future of agricultural trade relations with China and welcome a healthy U.S.-China economic relationship. Similar to previous pandemics or crises, the COVID-19 pandemic has led to an increase in non-tariff barriers, such as export restrictions on food products Martin and Glauber, 2020 and additional Sanitary and phytosanitary (SPS) measures. As politically motivated trade actions become more common, so do government trade aid payments such as the Market Facilitation Program (MFP), which, importantly, was not authorized by Congress Coppess et al. 2019]. I offer perspectives on the precedential importance of the MFP for future farm policy, and its distributional impacts across and within states. In addition, I discuss the declining global institutions of free trade and dwindling role of the WTO in global trade government, which in part results from the challenges in treating China's economic structure [Wu, 2016] and the ill-functioning WTO Appellate Body. I also show 
that although U.S. general public has a more unfavorable opinion of China, a vast majority of U.S. farmers recognize the paramount importance of maintaining a healthy economic relation with China. Recent surges in U.S. agricultural exports to China also led to more optimism among farmers [Mintert and Langemeier, 2020]. Finally, I provide reasoning for both China and the United States having critical interdependence in agricultural trade, and offer a cautiously optimistic conjecture on a more balanced U.S.-China agricultural trade portfolio with greater shares of protein and retail food products.

The rest of this paper proceeds as follows. Section 2 quantifies the impacts of COVID-19 on U.S. agricultural exports to China and China's predicted agricultural purchases under the phase one trade deal. Section 3 provides thoughts on the increasing importance of the political economy of trade actions and the possible rise of non-tariff barriers following the COVID-19 pandemic. Section 4 provides background on the U.S. public's increasingly negative views of China and on China's seemingly strategic efforts to increasingly diversify away from the United States even before the COVID-19 pandemic. Section 5 shows the somewhat more optimistic perceptions of U.S. farmers regarding the trade war and COVID19, at least in the long run. Finally, section 6 summarizes why healthy U.S.-China trade relations are imperative for both countries and how the phase one trade deal could possibly lead to a more balanced bilateral agricultural trade portfolio.

\section{The Impacts of COVID-19 and Phase One Trade Deal on U.S. Agricultural Exports to China}

The COVID-19 pandemic has resulted in major trade delays and created substantial uncertainty in U.S.-China agricultural trade relations. U.S.-China trade relations were already under pressure, especially in regards to the realization of the bilateral phase one trade deal both countries signed in January 2020. In the 88-page phase one deal, China made his-

toric and bold promises regarding buying U.S. agricultural and related products. In 2020 
and 2021, China pledged to buy $\$ 12.5$ and $\$ 19.5$ billion more in U.S. agricultural products, respectively, than it did in 2017. If realized, these will be the two highest agricultural export watermarks for U.S.-China agricultural trade ever. The feasibility of meeting phase one trade goals was questioned, due to the somewhat "unrealstic" export targets, even before the additional uncertainty created by COVID-19 Bown, 2020, Zhang, 2020]. For that reason, agricultural commodity markets did not rally immediately following the January 15, 2020, signing of the phase one deal, but instead dropped noticeably.

COVID-19's impacts on U.S. agricultural exports were initially due to China's measures to control the spread of the virus, which included lockdowns in Wuhan and other cities in Hubei province, as well as country-wide transport restrictions. In late February, three of China's biggest coastal ports - Shanghai, Ningbo and Xingang - were reportedly clogged with refrigerated containers full of imported vegetables, fruit, and frozen meat Bradsher and Chokshi, 2020. By late March, the overall work resumption index, which is based on mobile phone location data collected by Baidu, China's largest search engine, showed that about $20 \%$ of China's workers had not returned to work, especially those that worked in smaller firms [He et al., 2020b]. The labor shortage created challenges for China's imports and exports and worries about COVID-19 in China's ship crews led to tighter phytosatinary measures at both U.S. and China ports, which created additional logistical challenges for U.S. agricultural exports to China. These challenges impacted not only major products, such as soybeans and sorghum, but also influenced seafood products such as oysters, clams, and Dungeness crab [King, 2020]. Figure 11 shows monthly U.S. exports of agricultural and related products to China from January 2017 to July 2020. The flat red line for February and March 2020, which is lower than the same period from 2017 to 2019, clearly demonstrates the initial challenges posted by COVID-19 lockdowns in China.

[Insert Figure 1. Monthly U.S. agricultural and related products exports to China, $2017-2020]$ 
COVID-19's rapid global spread created a pending global economic recession, which led to a rapid rise in the U.S. dollar from February to May 2020. The strengthening of the U.S. dollar mainly stemmed from rising investor demand for safer investment options in a riskier COVID-19 world [Miller, 2020]. In contrast, the Brazil real depreciated more than $20 \%$ from early March to early May, which significantly boosted the price competitiveness of Brazil soybeans, a key competitor for a major U.S. agricultural export product. Brazil's increased competitiveness is problematic for U.S. agricultural exports for at least two reasons: (a) China's economy and agricultural imports have rapidly improved since early April as it largely contained the spread of COVID-19, which coincided the rapid depreciation of Brazil's currency; and, (b) the depreciation of the Brazil real came as China's soybean demand normally shifts from the United States to Brazil for seasonality reasons. For example, in the 2017/18 marketing year, 94\% of China's soybean imports were from September to March. Helped by the weakened currency, Brazil's soybean sales to China in June reached a record high 10.51 million tons - up 91\% from June 2019 and close to 95\% of all of China's soybean imports in June [Gu et al. 2020]. In the first seven months of 2020, China imported almost $70 \%$ of its soybeans from Brazil, which is much higher than the 2017 annual share of $52.8 \%$ Zhang, 2020]. The strength of Brazil's soybean exports is even more striking considering that Brazil became a COVID-19 hotspot in May 2020. More broadly, in the first half of 2020, China's total agricultural imports reached $\$ 80.7$ billion, a $33 \%$ increase from the $\$ 60.7$ billion in the first half of 2017 . However, China sourced $90 \%$ of its agricultural imports from non-U.S. sources in the first half of 2020, which, in part, reflects a continued diversification away from U.S. agricultural imports before and during the trade war He et al., 2020a. Furthermore, even as Chinese imports of U.S. pork reaches record level this year, it does not fully pass through to the producers because the COVID-19 led to temporary closures of packing plants and these plants do not source more pigs even seeing an export surge [Shike, 2020.

A more subtle impact of COVID-19 is related to the public debate among U.S. and 
China's officials over the origin of the virus and the optimal control measures. These debates exacerbate an already-fraught bilateral relation that is experiencing deterioration on multiple fronts from technology to national security. This has quickly given trade, originally a sore spot in U.S.-China relations, a calming effect in the bilateral relations, and it made negotiations of phase one trade deal implementation progress one of the few functioning communication channels. In other words, the phase one deal was already very important politically and symbolically because it represents the first time both countries actually made moves to reduce tariff rates rather than increase them [Zhang, 2020]. Deteriorating bilateral relations during the COVID-19 pandemic make the phase one deal even more significant, as evidenced by China's recent progress in purchasing U.S. agricultural products - China has imported a record 2.1 million metric tons of U.S. corn for the 2019/20 marketing year and as of September 10, 2020, has ordered 9.2 million metric tons of U.S. corn for delivery in the 2020/21 marketing year. China also has pre-booked 15.9 million metric tons of soybeans for delivery for the 2020/21 marketing year, and imported a record 514,400 metric tons of U.S. pork and 15,000 metric tons of U.S. beef in the first 36 weeks of 2020, much higher than levels in the full 2017 marketing year. [USDA, 2020a].

[Insert Table 1. China's Predicted Agricultural Imports of Key Commodities from February 15, 2020, to February 14, 2021]

Using linear extrapolation that accounts for seasonal patterns and trends, and assuming that advanced corn and soybean sales will be delivered in the first year of the trade deal, we predicted China's total U.S. and non-U.S. agricultural imports for 2020 He et al., 2020a] $!^{1}$ The prediction process is as follows: $(a)$ we obtain the monthly seasonal index by averaging the imports each month and dividing the monthly average by the overall average; $(b)$ we divide the actual data by the seasonal factors to get deseasonalized data and use that data to make a linear prediction to extrapolate deseasonalized imports from July to December

\footnotetext{
${ }^{1}$ This is joint work with Xi He and Dermot Hayes, and the most recent update can be found at https: //www.card.iastate.edu/products/policy-briefs/display/?n=1303
} 
2020, and from January to February 2021; and, (c) we then multiply the predicted imports from July to December 2020 and January to February 2021 by the seasonal index to get seasonalized imports. Table 1 presents our main predicted trade value and quantities, which shows that China is on track to import $\$ 21.63$ billion in agricultural products from the United States in the first year of the trade deal (February 15, 2020, to February 14, 2021). This is behind the target of $\$ 36.5$ billion, but recent market signals indicate that the pace of China's purchases is picking up. The gap between predicted imports and the promised quantity in the phase one deal clearly reflects the challenges imposed by COVID-19. However, the much larger purchase of Brazil, rather than U.S., soybeans also indicates China's continued strategic diversification away from key U.S. agricultural product purchases before the pandemic and even the start of the trade war.

Finally, the COVID-19 impacts on U.S.-China agricultural trade and U.S. overall agricultural exports could also be seen through assessing the relative significance of China among all U.S. trading partners before and during the pandemic. Figure 2 panel A presents for each agricultural commodity, how U.S. export values to China compare with the total exports to the world, while panel B shows the percentage change in U.S. agricultural exports by commodity and destination markets from January-July 2017 to January-July 2020 USDA, 2020b. Figure 2 panel A shows that China is a major buyer for many of U.S. agricultural products, and the purchase pace has exceeded the 2017 level for corn, beef, pork, and cotton despite the pandemic. In addition, panel $\mathrm{B}$ reveals that the COVID-19 pandemic has resulted in an overall 3-4\% drop in the total U.S. agricultural exports. The only bright spots are South Korea and ASEAN (Association of South-East Asian Nations) countries, which had a more rapid and effective response to the pandemic. In contrast, other major partners such as Mexico, Europe, and India are still experiencing rising COVID-19 infections and suffering from major economic shocks, which could limit their ability to significant boost purchases of U.S. agricultural products in the latter half of 2020. This cross-country comparison highlights even more the importance of Chinese purchases, especially the promised 
import surges as prescribed in the phase one trade deal, for the U.S. agricultural exports and economy overall. Even though the total Chinese imports as of July 2020 are still significantly less than the 2017 levels, the recent momentum discussed earlier offers more hope for a strong U.S.-China agricultural trade despite the pandemic. The recovering Chinese economy also signals China's ability in making these purchases and arguably many other trading partners of U.S. agriculture are still dealing with more economic trouble.

[Insert Table 2. China's Significance in U.S. Agricultural Exports Before and During COVID-19]

\section{Agricultural Trade Policies in a Post-COVID-19 World}

\subsection{The Rise of Non-tariff Barriers and Politically Motivated Trade Actions}

Due to the COVID-19 pandemic, several countries have placed export restrictions on medical supplies and food Martin and Glauber, 2020]. This also happened during the 2007-2008 food price spikes - many developing exporting countries introduced export restrictions such as bans, quotas, or taxes. In addition to the substantial impact on world food prices, these restrictions also encouraged other exporting countries to follow suit, which induced panic buying in importing countries Martin and Glauber, 2020]. Despite the ample storage of staple food in the world, more than 20 countries have issued export restrictions on food products in response to the COVID-19 pandemic [Glauber et al., 2020]. The export restrictions and recent floods in China have also led to heated discussions among China's public about food security, especially for key food items such as rice and wheat. This gives China more strategic incentives to evaluate on a commodity-specific basis the necessity of and dependence on imports from other countries, especially the United States. 
The COVID-19 pandemic led to more trade actions from China. As the Australia-China relations quickly deteriorated, China imposed $80 \%$ tariffs on Australian barley and banned exports of beef from four Australian abattoirs in May, and banned barley from the largest Australian barley exporter in September, reportedly over the threat of "harmful weeds" within the crop [Carey, 2020]. Since China is the largest importer of Australia barley, this could potentially boost U.S. exports of barley and other feed grains. However, at the same time, China also issued new demands for all food-exporting companies to sign documents stating that they comply with safety standards to prevent the transmission of COVID-19, which was met with rebuff from U.S. officials [Dorning, 2020]. This arguably affects protein exporters more as China issued a ban in June on poultry shipments from a Tyson Foods plant after the company reported infections in that Arkansas plant.

Worries about the channels through which COVID-19 can spread are also likely to increase sanitary needs and the corresponding sanitary and phytosanitary (SPS) measures, which will add trade cost. As tariff levels have been reduced worldwide, non-tariff barriers, including SPS measures, have gradually gained importance [Beghin, 2017]. As discussed earlier, market access is also an example of a non-tariff barrier, such as in China's decision not to open its market to U.S. beef. Even the products used to impose retaliatory tariffs are increasingly politically motivated - in 2018, a European Union retaliation targeted products from politically sensitive Republican-run U.S. states, which included the imposition of tariffs on Harley-Davidson motorcycles made in then-Speaker of the House Paul Ryan's home state of Wisconsin and duties on bourbon made in Senate Majority Leader Mitch McConnell's home state of Kentucky [Palmer and Behsudi, 2018]. Li et al. 2018] also review China's past trade retaliation strategies and find that one of its main goals of retaliatory tariffs is to inflict economic loss on politically influential interest groups in the United States, turning them into lobbyists for easing trade restrictions.

The elevated political significance of the U.S.-China phase one deal due to the COVID-19 pandemic also has the potential to change global trade negotiation and governance. Even 
before the pandemic, the phase one trade deal was criticized for representing a "managed trade" approach to expanding U.S. exports by potentially diverting trade from other countries Bown, 2020, as opposed to addressing and reducing China's specific tariff and non-tariff barriers, which was the efforts of previous bilateral or multilateral trade negotiations. By emphasizing U.S.-centered outcomes or purchase targets, the United States is effectively initiating a change from "rules-based" trade negotiations to "power-based" tariff bargaining Mattoo and Waiger, 2019], undermining the already declining role of the WTO in global trade governance. In fact, the WTO was already facing growing challenges in regards to how it treats China's economic structure [Wu, 2016, and the Trump administration effectively disarmed the WTO Appellate Body, a key settlement mechanism, by blockading appointments of its judges Hillman, 2020]. The WTO panel just ruled against $\$ 200$ billion in U.S. tariffs on China's products; however, this ruling does not have much practical impact, at

least in the short term, because the U.S. could appeal the decision and the WTO Appellate Body is not functioning without enough judges Keaten, 2020]. These actions represent a major policy shift in the United States toward "economic dis-integration" in the name of "America First" Chow et al., 2019]. However, Europe, China, and 14 other WTO members agreed on a temporary mechanism to resolve trade disputes [Blenkinsop, 2020], which highlights the diminishing role of the United Sates in international trade governance as it embraces economic nationalism Chow et al., 2019.

\subsection{The Rise of Trade Aids in Government Payments and the Distributional Impacts}

The COVID-19 pandemic has caused most agricultural markets to significantly lower, generated considerable price volatility, and resulted in significant sales and income loss for many producers Lusk and Anderson, 2020]. To partially offset sales losses and increased marketing costs associated with the pandemic, the U.S. Congress enacted new legislation and programs to provide producers with financial assistance. A key program is the $\$ 16$ billion 
dollar Coronavirus Food Assistance Program (CFAP), which compensates producers' losses incurred prior to April 15th through a combination of $\$ 9.5$ million in CARES (Coronavirus Aid, Relief, and Economic Security) Act funding and $\$ 6.5$ million in Commodity Credit Corporation (CCC) funding [Tidgren, 2020]. As of mid-September, 2020, nearly $\$ 10$ billion of CFAP payments have been made to cattle, dairy, corn, hog, and soybean producers. In addition, a new CFAP2 program totaling nearly $\$ 14$ billion dollars were recently announced to provide additional aid to partially offset COVID-19-related losses for corn, cattle, and other producers Newton and Nepveux, 2020 2 2 Part of the funding for CFAP2 will come from the CCC as well.

The CFAP and CFAP2 funds were created in response to the the COVID-19 pandemic and are not part of the usual farm bill. Currently, the CFAP and CFAP2 funding coming from the CCC funds are estimated to almost use up its $\$ 30$ billion borrowing capacity. As a result, USDA likely does not have sufficient resources to meet upcoming farm bill and conservation program payments beyond October without an immediate replenishment of the CCC in a continuing resolution [Newton and Gerlt, 2020]. However, the current pandemic is not the first time the United States has used an ad hoc farm policy response with direct government payments. In fact, the 2018 and 2019 trade aid payments, which totaled $\$ 28$ billion dollars, were distributed through the MFP, which was not authorized by Congress in either the 2018 Farm Bill or in any ad hoc appropriations legislation Coppess et al., 2019. The MFP relied on USDA's "arguably very creative" interpretation of CCC authorities Coppess et al., 2019], yet Congress later implicitly endorsed the action by replenishing CCC borrowing capacity. The sheer size of the MFP payments dwarfs previous direct payment programs in the most recent farm bills and thus potentially establish precedents for U.S. farm policy going forward and significantly expand the reach of the executive branch of the

\footnotetext{
${ }^{2}$ In contrast, the Chinese response to COVID-19 is not individual tax cuts or direct payments to residents or producers. Instead, China's responses focused on corporate tax cuts such as value added tax exemptions to boost the firms' production decisions, as well as special government bonds that are worth US\$14 billion to incentivize investments in local infrastructure [CGTN, 2020]. China's central bank also issued two special loan programs worth US $\$ 115$ billion dollars to support production of medical supplies and resumptions of China's workforce Cheng, 2020.
} 
U.S. government [Coppess et al., 2019]. The rising distrust between the United States and China may yield more politically motivated trade actions, which will call for more expansive use of trade relief programs and potentially bypass Congress in the fashion of the MFP.

The MFP represents a major redirection of farm policy away from Congress's decoupling efforts that started with the 1996 Farm Bill Coppess et al. 2019. These past U.S. efforts, along with the European Union's Common Agricultural Policy, were redesigned to meet WTO rules, liberalize trade, and reduce agricultural protectionism. For example, U.S. farm bills have shifted toward decoupled farm programs that provide income support without relation to current production, factor use, or prices Bhaskar and Beghin, 2009. A key reason is that these decoupled farm policies are classified as green-box payments and are thus exempt from WTO disciplines. However, MFP payments require planting a crop and are tied to production - the 2018 payments were based on actual production records and the 2019 payments were based on county-level acres [Glauber, 2019], which sets a controversial precedent in the direction of future U.S. farm policy.

Finally, the MFP effectively serves as a massive income transfer of taxpayer funds to farmers and agricultural states, as congressional authorization replenishes funds for CCC payments but the funds come from the U.S. Treasury. Given that the ongoing U.S.-China trade war impacts almost all sectors of the U.S. economy and covers over $90 \%$ of all U.S. exports Wong and Koty, 2020, the MFP shifts the state-level burden of the trade war because the payments have a real cost in terms of budget opportunities and distorts the distributional impacts and perceptions of the U.S.-China trade war. Our previous analysis reveal that many Midwest states experience net welfare gains as MFP payments totally offset the incidence of tariff retaliation on the state economy [Balistreri et al. 2020]. In general, the "winner" states are "red" states that voted for President Trump in the 2016 election that disproportionately rely on their agricultural sector for income and received substantial MFP payments Balistreri et al. 2020]. In contrast, because the burden of tax revenues falls on all citizens, more populous urban states, such as California, and urban areas with high 
populations bear higher costs of raising these tax revenues. Moreover, the net welfare effect for key battleground "purple" states such as Michigan, Ohio, Wisconsin, and Pennsylvania remain negative. With the potential increase in ad hoc farm policy in the fashion of the MFP, which essentially requires taxpayer funds, it is increasingly important for Congress and the public to more closely examine the political economy and the impacts of these ad hoc policies Coppess et al. 2019.

\section{COVID-19 Exacerbated the Fracturing U.S.-China Relations}

According to two prominent polls of the U.S. public in the middle of the COVID-19 pandemic, the U.S. public, in general, is increasingly viewing China more negatively. Figure 2 shows the change in the number of U.S. adults who say they have an unfavorable opinion of China over the past 15 years [Devlin et al., 2020]. Despite important differences across the population, figure 2 clearly indicates that the U.S. public's view of China has become increasingly negative, especially over the past decade. In particular, the share of U.S. adults who harbor an unfavorable opinion of China has jumped from 35\% in 2005 to almost two-thirds in 2020. Figure 2 also shows that older U.S. residents and Republicans consistently think more negatively about China than their younger counterparts and those identifying as Democrats. Even among the cohort that is most likely to have a favorable view of China-young adults ages 18-29-more than half now view China unfavorably. Similarly, the attitudes of China's public toward the United States have quickly deteriorated as well. The share of China's adults having a favorable opinion of the United States declined from $58 \%$ in 2010 to $40 \%$ in 2013 Kohut, 2013], which is the most recent survey. The deterioration in favorable public opinions of China could be a result of China's growing economic and political power and worry about its strategic competition with the United States [Zhao, 2019].

A recent Harris poll echoes the Pew findings - it shows that the COVID-19 pandemic 
is turning both the U.S. Republican and Democratic Parties against China. In particular, Republicans and Democrats now largely agree that China's government bears responsibility for the spread of the pandemic, that it can't be trusted on this or any other issue, and that the U.S. government should maintain a tough position on China on trade and overall, especially if Beijing again falters in its commitments Rogin, 2020. In other words, the COVID-19 pandemic has exacerbated the already-deteriorating good will among the U.S. public toward China.

[Insert Figure 2. Percent of U.S. adults that say they have an unfavorable opinion of China]

Figure 2 also shows that public opinions fluctuate with current events - for example, the decline in negative views in the late 2010s probably reflects the cooperation among the United States, China, and Europe in combating the 2007-2009 Great Recession, while the recent uptick in unfavorable opinions since 2017-2018 largely reflect the ongoing U.S.-China trade war. Since 2018, U.S. trade disputes with China have quickly deteriorated into a full-blown trade war with more than $90 \%$ of products experiencing significant tariff increases from one or both countries Wong and Koty, 2020. In particular, as of fall 2019, China's retaliatory tariffs covered almost all U.S. agricultural products Bown and Kolb, 2020, Zhang, 2019], which led to significant economic damage to the U.S. agricultural economy, especially U.S. agricultural exports to China Balistreri et al., 2018]. Furthermore, the so-called Superpower Showdown has negatively impacted both countries' economies [Li et al., 2020] as well as escalated tensions on multiple fronts and created even greater uncertainty about the future Davis and Wei, 2020].

[Insert Figure 3. China's continued diversification away from U.S. agricultural imports]

Although the recent tensions escalated over the past three years, the United States and China have a long and sometimes fraught political and economic history that has seen frequent disruptions. The U.S. agricultural community expresses a growing frustration with 
China's erratic agricultural purchase behaviors. For example, in 2003, China shut out U.S. beef over a mad cow disease scare and kept the ban for 14 years - more than a decade after other countries such as Japan and South Korea lifted theirs [Zhang et al., 2019]. Figure 3 presents two graphs to illustrate China's accelerated diversification away from U.S. agricultural imports over the past decade, well before the start of the recent trade war or the Trump presidency. In particular, the orange line in figure 3a represents the U.S. share of China's total imports of agricultural and related products, while the green line shows the share of U.S. agricultural and related product exports sent to China. These two graphs show that over the past decade, especially since China's President Xi took office in 2012, both shares have continuously dropped, falling from $23 \%$ and $17 \%$, respectively, to slightly over $10 \%$ in 2018. In other words, figure 3a reflects China's strategic diversification in imports of agricultural and energy products as well as raw materials, accomplished partly through expanding the Belt and Road Initiative Xiong and Zhang, 2019, Zhang, 2019]. Figure 3breplicates the two shares shown in figure 3a separately for soybean and pork trade. Figure 3a shows that China consistently bought about $60 \%$ of U.S. soybean exports over the past decade, which represents about one-quarter of the entire U.S. soybean crop. However, the steady demand for U.S. soybeans still represents a decreasing share of China's total soybean and feed grain demand, as China has increasingly relied on Brazil for soybeans Gale et al., 2019. This is in part due to growing production of corn and soybeans in Brazil over the past decade, as well as a rapid depreciation of the Brazil real since early 2018. Similarly, while China bought more U.S. pork from 2010 to 2020 than it did in the previous decade, the relative importance of U.S. pork in China's total pork imports still decreased sharply $3_{3}^{3}$

\footnotetext{
${ }^{3}$ Before the 2018 African swine fever outbreak, China's pork consumption was largely self-sufficient-it was able to produce $97 \%$ of its pork demand domestically Xiong and Zhang, 2019. As a result, the high percentages of U.S. pork in China's pork imports do not represent large quantities, as China imported more pork from European countries by taking advantage of better transportation connections with the Belt and Road Initiative Xiong and Zhang, 2019].
} 


\section{The Silver Lining: More Encouraging Views from U.S. Farmers}

Recognizing the U.S. public's more unfavorable sentiments toward China and the critical role

of U.S. farmers in influencing agricultural and trade policies, Qu et al. 2019] conducted a survey in early 2019 of Midwest crop farmers on their perceptions and views of the U.S.-China trade war. 693 crop farmers in Minnesota, Iowa, and Illinois with at least 250 operating acres of corn or soybeans responded to this mixed-mode survey from February to April 2019, yielding an effective response rate of $23 \%$. Table 3 shows that in the middle of the trade war in spring 2019, the surveyed crop farmers voiced concerns about China's trade and economic practices Qu et al. 2019. In particular, more than 70\% of respondents agreed or strongly agreed with the statements "The amount of U.S. debt held by China is a serious problem for the U.S.," "The trade deficit with China is harmful to the U.S. economy," and "China engages in cyber-economic espionage against the U.S." Similarly, less than $5 \%$ of respondents disagreed or strongly disagreed with the statements "The Chinese government exerts too much influence on the value of its currency" and "China's record of enforcing intellectual property rights leaves much to be desired." These views show the majority of farmers negatively relate current debt deficits and job losses with China and China's governmental practices regarding intellectual property protection and currency. These perceptions, along with the recognition of income support from the MFP Glauber, 2019, explain the finding that over $56 \%$ were still somewhat (34\%) or strongly supportive (22\%) of President Trump's tariffs on Chinese products Qu et al., 2019.

[Insert Table 3. U.S. Midwest Farmers' Perceptions of the U.S.-China Trade War and Economic Relations, Spring 2019]

In addition to confirming the views of the U.S. general public, table 3 also reveals several more encouraging views regarding trade and economic relations with China. In particular, table 3 shows that an overwhelming majority of respondents to the 2019 survey (92\%) 
agreed or strongly agreed that it is important for the United States to maintain a healthy economic relationship with China. Furthermore, although farmers split equally on the statement "Economically, China is an ally of the U.S.," only $20 \%$ of respondents disagreed or strongly disagreed with the statement "China's growing economic strength is good for the world." Finally, most U.S. farmers (75\%) recognized that they would bear the brunt of the tariffs imposed by China, and many (81\%) hoped the trade disruption would be resolved soon. These more optimistic views of China's importance for U.S. agricultural markets and the importance of maintaining a healthy bilateral economic relationship are important to recognize, especially because they were made during the thick of trade tensions.

[Insert Figure 4. Producers' views about U.S.-China agricultural trade from Ag Economy Barometer 2019-2020]

The uplifting impact of the U.S.-China trade deal on farmers' sentiments after, and even before, the signing of the trade deal are reflected in the monthly producer Ag Economy Barometer survey led by Purdue University and the CME Group (see figure 4). In particular, the share of producers who think that the trade dispute with China will likely be settled soon, shown as the blue line in figure 4b, almost doubled in late 2019 and peaked in January 2020 when the phase one deal was signed. Figures $4 \mathrm{a}$ and $4 \mathrm{~b}$ also show the impacts of the COVID-19 pandemic on producers' future outlooks. In particular, the share of producers expecting an increase in U.S. agricultural exports over the next five years dropped from $70 \%$ to less than $60 \%$ over the past four months, and the percent of producers who think the trade dispute with China will ultimately be resolved in a way that benefits U.S. agriculture dipped by 20 percentage points to less than $60 \%$ as well. However, it is also important to point out that both percentages that indicate a more optimistic future outlook are still above $50 \%$ even during the pandemic. Furthermore, Figure $4 \mathrm{a}$ also shows that the percent of producers expecting increasing exports spiked to $67 \%$ in August, reflecting in part rising export sales to China this summer Mintert and Langemeier, 2020]. This is also consistent with table 3, which shows that more surveyed crop farmers agree than disagree with the 
statement "The trade disruption will enhance the economic relationship between the U.S. and China in the long run." This figure also shows that as commodity prices rally and U.S.China agricultural trade prospects improve, the index of current conditions, which measures the producer sentiment, rose from 70 in April to 124 in August 2020.

\section{The Path Forward: A Cautiously Optimistic View about Future U.S.-China Agricultural Trade}

The COVID-19 pandemic caused significant delays, uncertainty and challenges for U.S.China agricultural trade relations, and economic relations in general. This in part arises from challenges with more workers working from home as well as the rise in non-tariff barriers. In addition, the ongoing trade war and the quick deterioration of U.S.-China relations and mutual trust during the pandemic also gives China even more strategic incentives to continue accelerating its diversification [Zhang, 2019]. As a result, China's purchases of agricultural exports are currently noticeably below the phase one trade deal's annual year-end targets He et al. 2020a.

However, this does not necessarily lead to a gloom-and-doom scenario for future agricultural trade relations between China and the United States. Table 3 reveals that a majority of U.S. farmers recognize and welcome healthy U.S.-China economic relations. I would argue that healthy bilateral trade relations are mutually beneficial, politically significant, and economically indispensable for both countries. From China's perspective, the United States is indispensable because commodity agricultural production, especially if it is land-intensive, is not China's comparative advantage [Zhang, 2019]. In particular, China only has half the arable land of the United States, yet it has almost 90 times as many farmers actively engaged in crop or livestock production, which results in an average of less than two U.S. acres for a typical farming household. Furthermore, China's agricultural production efficiency is

also severely constrained by inferior land quality and lagging technological progress in crop 
and livestock genetics Zhang, 2019. These limitations, combined with farmland lost to urbanization, led to China only producing 15\%-20\% of its soybean needs domestically and instead using most of its arable acres for major food crops such as rice, wheat, and corn. With a rising per-capita income and protein consumption, China cannot afford to go without the United States, which prides itself as a cost-competitive major supplier of multiple agricultural products. From the perspective of the United States, China represents a critical and growing market with rising demand from its expanding middle class. In particular, the Brookings Institution estimates that $88 \%$ of the global middle class over the next decade will be in China, India, and other Asian countries-Asia's middle-class markets are set to grow from $\$ 20$ trillion today to $\$ 36$ trillion by 2030 [Kharas, 2020]. China's economic growth has already led to noticeable increases in household income and demand for protein, which created surging import demand for products like beef and avocados [Zhang, 2019].

Although the bold purchase targets promised in the U.S.-China phase one trade deal may not materialize in the long run, they do offer an important opportunity to restructure U.S.China agricultural trade relations. Current U.S.-China agricultural trade is dominated by feed grains, especially soybeans; however, the phase one deal offers an opportunity for both countries to upgrade to a more balanced portfolio of U.S. agricultural exports to China, with long-term growth in meat, seafood, and retail food products [Zhang, 2020]. With projected increases in soybean and corn production in Brazil and grain production in Ukraine and Russia, the long-term U.S. market share of soybeans could fall. China's total 2017 agricultural imports exceeded $\$ 140$ billion; however, the United States accounts for very small fractions of China's meat, seafood, and retail food product demand [Zhang, 2020]. China is the world's largest meat buyer and is currently battling an unprecedented pork shortage due to an African swine fever outbreak. As a result, the meat shortage created by China's ongoing African swine fever outbreak is continuing to result in rising demand from China for U.S. pork, beef, and poultry products He et al. 2020a. Germany is currently China's thirdlargest pork supplier; however, China is now banning imports of Germany pork after the 
latter confirmed its first African swine fever case. Germany is a key U.S. competitor in the global pork market; thus, the United States is poised to ship more pork to China Reuters, 2020]. Similarly, it is also reasonable to expect the United States to capture a larger share of China's imports as it buys more consumer products such as nuts, fruits and vegetables, wine, seafood, and dairy products. The more balanced portfolio will allow China to strengthen economic ties with agricultural states outside the U.S. Midwest, such as California and Florida, and also fits China's diversification objectives of not solely relying on soybeans when buying U.S. agricultural products. However, these increases in protein, especially consumer products, won’t happen automatically as other countries such as Australia, New Zealand, and Chile strengthen economic ties with China. To maintain the U.S. export competitiveness as U.S. agriculture continue to heavily rely on international demand, there is a greater demand for Extension programming to help producers and consumers better understand international markets such as China [Taylor and Zhang, 2019]. A better knowledge of the growing Chinese middle class will also help identify more concrete "exchanges and dialogues on agricultural topics" between the United States and China, as prescribed in the phase one trade deal U.S. Trade Representative, 2020]. All these suggest creative thinking will help rebuild mutual trust and good will among the two nations.

The COVID-19 pandemic and the ensuing rise in deglobalization pressures add more uncertainty to future U.S.-China agricultural trade and the phase one trade deal. Despite the challenges in meeting the purchase targets, there is still room for cautious optimism, as China has accelerated its agricultural purchases from the United States and made good progress meeting the regulatory and structural changes promised in the deal He et al., 2020a]. The phase one deal is important both politically and symbolically because it represents the first time both countries made moves to actually reduce the tariff rate rather than escalate the situation. In a world with rising economic nationalism and growing distrust, stressing healthy U.S.-China trade relations, for the well-being of both U.S. farmers and China's consumers, is paramount. 


\section{References}

E. J. Balistreri, C. E. Hart, D. J. Hayes, M. Li, L. Schulz, D. A. Swenson, W. Zhang, and J. M. Crespi. The impact of the 2018 trade disruptions on the iowa economy. CARD Policy Briefs 18-PB 25, Center for Agricultural and Rural Development, Iowa State University, 2018. URL https://www . card. iastate.edu/products/publications/synopsis/?p=1281.

E. J. Balistreri, W. Zhang, and J. Beghin. The state-level burden of the trade war: Interactions between the Market Facilitation Program and tariffs. CARD Agricultural Policy Review, Winter:1-3, 2020.

J. C. Beghin. Nontariff Measures and International Trade, volume 56 of World Scientific Studies in International Economics. World Scientific, January 2017. doi: https://doi.org/ 10.1142/10150.

A. Bhaskar and J. C. Beghin. How coupled are decoupled farm payments? a review of the evidence. Journal of Agricultural and Resource Economics, 34(1):130-153, 2009. URL https://www.jstor .org/stable/41548405.

P. Blenkinsop. EU, China and 14 others agree stop-gap fix for WTO crisis. Reuters Business News, (March 27), 2020. URL https://www.reuters.com/article/us-trade-wto/ eu-china-and-14-others-agree-stop-gap-fix-for-wto-crisis \-idUSKBN21E2I0.

C. P. Bown. Unappreciated hazards of the US-China phase one deal. Technical report, Peterson Institute for International Economics, 2020. URL https://www.piie.com/blogs/trade-and-investment-policy-watch/ unappreciated-hazards-us-china-phase-one-deal.

C. P. Bown and M. Kolb. Trump's trade war timeline: An up-to-date guide. Technical report, Peterson Institute for International Economics, 2020. URL https://www.piie. com/blogs/trade-investment-policy-watch/trump-trade-war-china-date-guide.

K. Bradsher and N. Chokshi. Virus Disrupts China's Shipping, and World Ports Feel the Impact. the New York Times, 2020. URL https://www.nytimes.com/2020/02/ 27/business/economy/china-coronavirus-shipping-ports.html.

A. Carey. China bans Australian barley imports as trade war escalates. Bloomberg, 2020. URL https://www.news.com.au/finance/business/other-industries/ china-bans-australian-barley-imports-as-trade-war-escalates/news-story/ 4d1bf27e91cf5a47e2165983a1a91081.

CGTN. China confident of meeting 2020 fiscal targets: Finance minister. CGTN, 2020. URL https://news.cgtn.com/news/2020-08-07/ China-confident-of-meeting-2020-fiscal-targets-Finance-Minister-SKUFJsrke4/ index.html.

E. Cheng. China's central bank sees little need for more emergency stimulus this year. CNBC, 2020. URL https://www.cnbc.com/2020/07/13/ chinas-central-bank-sees-little-need-for-more-stimulus-this-year.html. 
D. C. Chow, I. M. Sheldon, and W. McGuire. The revival of economic nationalism and the global trading system. Cardozo Law Journal, page 2133, 2019. URL https://dx.doi. org/10.2139/ssrn.3152299.

J. Coppess, G. Schnitkey, K. Swanson, and C. Zulauf. The Market Facilitation Program: A new direction in public agricultural policy? 9 (220), 2019. URL https://farmdocdaily.illinois.edu/2019/11/ the-market-facilitation-program-a-new-direction-in-public-agricultural-policy . html.

B. Davis and L. Wei. Superpower Showdown: How the Battle Between Trump and Xi Threatens a New Cold War. HarperCollins, 2020. ISBN 9780062953056.

K. Devlin, L. Silver, and C. Huang. U.S. views of China increasingly negative amid coronavirus outbreak. April 2020. URL https://www.pewresearch.org/global/2020/04/ 21/u-s-views-of-china-increasingly-negative-amid-coronavirus-outbreak/.

M. Dorning. U.S. Rebuffs China, Rejecting Links Between Covid and Food. Bloomberg, 2020. URL https://www.bloomberg.com/news/articles/2020-06-24/ in-rebuff-to-china-u-s-snubs-any-link-between-covid-and-food?sref= q8seIhDd.

F. Gale, C. Valdes, and M. Ash. Interdependence of China, United States, and Brazil in soybean trade. Oil Crops Outlook OCS-19F-01, USDA Economic Research Service, 2019. URL https://www .ers.usda.gov/publications/pub-details/?pubid=93389.

J. Glauber, D. Laborde, W. Martin, and B. Vos. Covid-19: Trade restrictions are worst possible response to safeguard food security. IFPRI Blog, March 2020. URL https://www.ifpri.org/blog/ covid-19-trade-restrictions-are-worst-possible-response-safeguard-food-security.

J. W. Glauber. Agricultural trade aid: Implications and consequences for us global trade relationships in the context of the World Trade Organization. Technical report, American Enterprise Institute (AEI), 2019. URL https://www.aei.org/research-products/report/ agricultural-trade-aid-implications-and-consequences-for-us-global-traderelationships-in-the-context-of-the-world-trade-organization/.

J. W. Glauber. Trade restrictions are the wrong way to address food supply issues in the covid-19 crisis. the Hill, 2020. URL https://thehill.com/opinion/finance/ 496875-trade-restrictions-are-the-wrong-way-to-address-food-supply-issues-in-the.

H. Gu, P. Li, and D. Patton. China's soybean imports from Brazil rise to record in June. Reuters, 2020. URL https: //www.reuters.com/article/us-china-economy-trade-soybeans/ chinas-soybean-imports-from-brazil-rise-to-record-in-june-idUSKCN24R07Q. 
Y. N. Harari. the world after coronavirus. the Financial Times, 2020. URL https://www. ft.com/content/19d90308-6858-11ea-a3c9-1fe6fedcca75.

X. He, D. J. Hayes, and W. Zhang. China's agricultural imports under the phase one deal: Is success possible? CARD Policy Briefs 20-PB 29, Center for Agricultural and Rural Development, Iowa State University, 2020a. URL https://www.card.iastate. edu/products/policy-briefs/display/?n=1303.

X. He, T. Xiong, and W. Zhang. [covid-19 economic database: China], August 2020b. URL https://www. card.iastate.edu/china/covid-19/.

J. A. Hillman. A Reset of the World Trade Organization's Appellate Body. Technical report, Greenberg Center for Geoeconomic Studies, Council on Foreign Relations, January 2020. URL https://www.cfr.org/report/ reset-world-trade-organizations-appellate-body.

International Monetary Fund. World economic outlook update, june 2020: A crisis like no other, an uncertain recovery. Technical report, 2020. URL https://www.imf.org/en/ Publications/WEO/Issues/2020/06/24/WEOUpdateJune2020.

J. Keaten. US tariffs on China are illegal, says world trade body. the AP News, 2020. URL https://apnews.com/58a89252300408e255ed3a9a26004091.

H. Kharas. Who gained from global growth last decade - and who will benefit by 2030? Future development blog, the Brookings Institution, January 2020. URL https://www.brookings.edu/blog/future-development/2020/01/16/ who-gained-from-global-growth-last-decade-\and-who-will-benefit-by-2030/.

A. King. Northwest Exports Back Up As Coronavirus Quarantines Trade. Oregon Public Broadcasting, 2020. URL https://www.opb.org/news/article/ coronavirus-pacific-northwest-us-china-trade-exports-oregon-washington/.

A. Kohut. America's Global Image Remains More Positive than China's: But Many See China Becoming World's Leading Power.

(July), 2013. URL https://www.pewresearch.org/global/2013/07/18/ americas-global-image-remains-more-positive-than-chinas/.

M. Li, W. Zhang, and C. Hart. What have we learned from China's past trade retaliation strategies? Choices, 8(2), 2018.

M. Li, E. Balistreri, and W. Zhang. The U.S.-China trade war: Tariff data and general equilibrium analysis. Journal of Asian Economics, 2020. doi: https://doi.org/10.1016/j. asieco.2020.101216.

J. Lusk and J. D. Anderson. Economic Impacts of COVID-19 on Food and Agricultural Markets. the Council for Agricultural Science and Technology (CAST), 2020. URL https://www.cast-science.org/publication/ economic-impacts-of-covid-19-on-food-and-agricultural-markets/. 
W. Martin and J. W. Glauber. Chapter 6 - trade policy and food security. In R. E. Baldwin and S. J. Evenett, editors, COVID-19 and trade policy: Why turning inward won't work, pages 89-101. CEPR Press, 2020. URL https://voxeu.org/content/ covid-19-and-trade-policy-why-turning-inward-won-t-work.

A. Mattoo and R. W. Waiger. Trade wars: What do they mean? why are they happening now? what are the costs? NBER Working Paper, (25762), April 2019. URL https: //www . nber . org/papers/w25762.

C. Miller. The dominance of the u.s. dollar during the covid-19 pandemic. 2020. URL https://www.fpri.org/article/2020/05/ the-dominance-of-the-u-s-dollar-during-the-covid-19-pandemic/.

J. Mintert and M. Langemeier. Farmer sentiment rebounds as commodity prices rally and agriculture trade prospects improve. Purdue University / CME Group Ag Economy Barometer, September 2020. URL https://ag.purdue.edu/commercialag/ageconomybarometer/ farmer-sentiment-rebounds-as-commodity-prices-rally-and-agriculture-trade-prospects-i

J. Newton. Covid-19 will likely push farm bankruptcies higher. Market Intel, American Enterprise Institute (AEI), 2020. URL https://www.fb.org/market-intel/ covid-19-will-likely-push-farm-bankruptcies-higher.

J. Newton and S. Gerlt. Farm Bill Programs At Risk Without Immediate CCC Replenishment. Market Intel by American Farm Bureau Federation, September 2020. URL https://www.fb.org/market-intel/ farm-bill-programs-at-risk-without-immediate-ccc-replenishment.

J. Newton and M. Nepveux. Breaking Down CFAP2. Market Intel by American Farm Bureau Federation, September 2020. URL https://www.fb.org/market-intel/ breaking-down-cfap-2.0.

D. Palmer and A. Behsudi. Trade wars: Tariffs on bourbon, harleys and blue jeans. Politico, March 2018. URL https://www.politico.com/story/2018/03/02/ trump-tariffs-world-response-382959.

Purdue University. Ag Economy Barometer, 2020. URL https://ag.purdue.edu/ commercialag/ageconomybarometer/charts/.

S. Qu, W. Zhang, M. Li, L. Rodriguez, G. Han, E. Cork, and J. M. Gbeda. Midwest crop farmers' perceptions of the U.S.-China trade war. CARD Policy Briefs 19-PB 26, Center for Agricultural and Rural Development, Iowa State University, 2019. URL https: //www. card.iastate.edu/products/policy-briefs/display/?n=1294

Reuters. China bans German pork imports after African swine fever case. Reuters, 2020. URL https://www.reuters.com/article/germany-swinefever-china/ china-bans-german-pork-imports-after-african-swine-fever-case-idUSKBN2630GW. 
J. Rogin. The coronavirus crisis is turning americans in both parties against china. the Washington Post, 2020. URL https://www.washingtonpost.com/opinions/2020/04/ 08/coronavirus-crisis-is-turning-americans-both-parties-against-china/.

I. Sheldon and J. Grant. Global trade in agricultural products: The likely impact of covid19. In J. Lusk and J. D. Anderson, editors, Economic Impacts of COVID-19 on Food and Agricultural Markets, pages 5-9. the Council for Agricultural Science and Technology (CAST), 2020. URL https://www.cast-science.org/wp-content/uploads/2020/06/ QTA2020-3-COVID-Impacts.pdf.

J. Shike. Link between Exports and Hog Prices. Pork Network by the Farm Journal, 2020. URL https://wwW.porkbusiness.com/article/ link-between-exports-and-hog-prices.

M. Taylor and W. Zhang. Training the next generation of Extension economists. Choices, (2), 2019. URL https://www.choicesmagazine.org/ choices-magazine/theme-articles/the-future-of-farm-management-extension/ training-the-next-generation-of-extension-economists.

K. Tidgren. Usda releases final rule for coronavirus food assistance program. (May 19), 2020. URL https://www.calt.iastate.edu/blogpost/ usda-releases-final-rule-coronavirus-food-assistance-program.

U.S. Trade Representative. Economic and Trade Agreement Between the Government of the United States of America and the Government of the People's Republic of China. Technical report, 2020. URL https://ustr.gov/countries-regions/china-mongolia-taiwan/ peoples-republic-china/phase-one-trade-agreement/text.

USDA. U.S. Export Sales Report ((Data for Week Ending September 10, 2020), 2020a. URL https://apps.fas.usda.gov/export-sales/esrd1.html.

USDA. Global agricultural trade system (gats), 2020b. URL https://apps.fas.usda.gov/ gats/default.aspx.

USDA Economic Research Service. Highlights from the february 2020 farm income forecast: Farm sector profits forecast near average in 2020, February 2020. URL https://www.ers.usda.gov/topics/farm-economy/farm-sector-income-finances/ highlights-from-the-farm-income-forecast/.

D. Wong and A. C. Koty. The US-China trade war: A timeline. Technical report, Dezan Shira and Associates, 2020. URL https://www.china-briefing.com/news/ the-us-china-trade-war-a-timeline/. Accessed: 06/01/2020.

M. Wu. The "China, Inc." challenge to global trade governance. Harvard International Law Journal, 57(2):261-324, 2016.

T. Xiong and W. Zhang. Who benefits most from China's growing import demand due to African Swine Fever? (August), 2019. URL https://www.extension.iastate.edu/ agdm/articles/others/XioAug19.html. 
T. Xiong and W. Zhang. The coronavirus will delay agricultural export surges promised in trade deal with China. (March), 2020. URL https://theconversation.com/ the-coronavirus-will-delay-agricultural-export-surges-promised-in-trade-deal \ -with-china-132227.

W. Zhang. Seven things to know about China to understand the trade war. (February), 2019. URL https://www. extension.iastate. edu/agdm/articles/zhang/ZhaFeb19.html.

W. Zhang. US-China Phase 1 Trade Deal and US agriculture: A big win for farmers or too good to be true? (February), 2020. URL https://www.extension.iastate.edu/agdm/ articles/zhang/ZhaFeb20.html.

W. Zhang, L. Rodriguez, and S. Qu. 3 reasons Midwest farmers hurt by the U.S.-China trade war still support Trump. (November), 2019. URL https://theconversation.com/ 3-reasons-midwest-farmers-hurt-by-the-u-s-china-trade-war-still-support- 1 trump-126303.

M. Zhao. Is a new Cold War inevitable? Chinese perspectives on US-China strategic competition. The Chinese Journal of International Politics, 12(3):371-394, 2019. doi: https://doi.org/10.1093/cjip/poz010. 


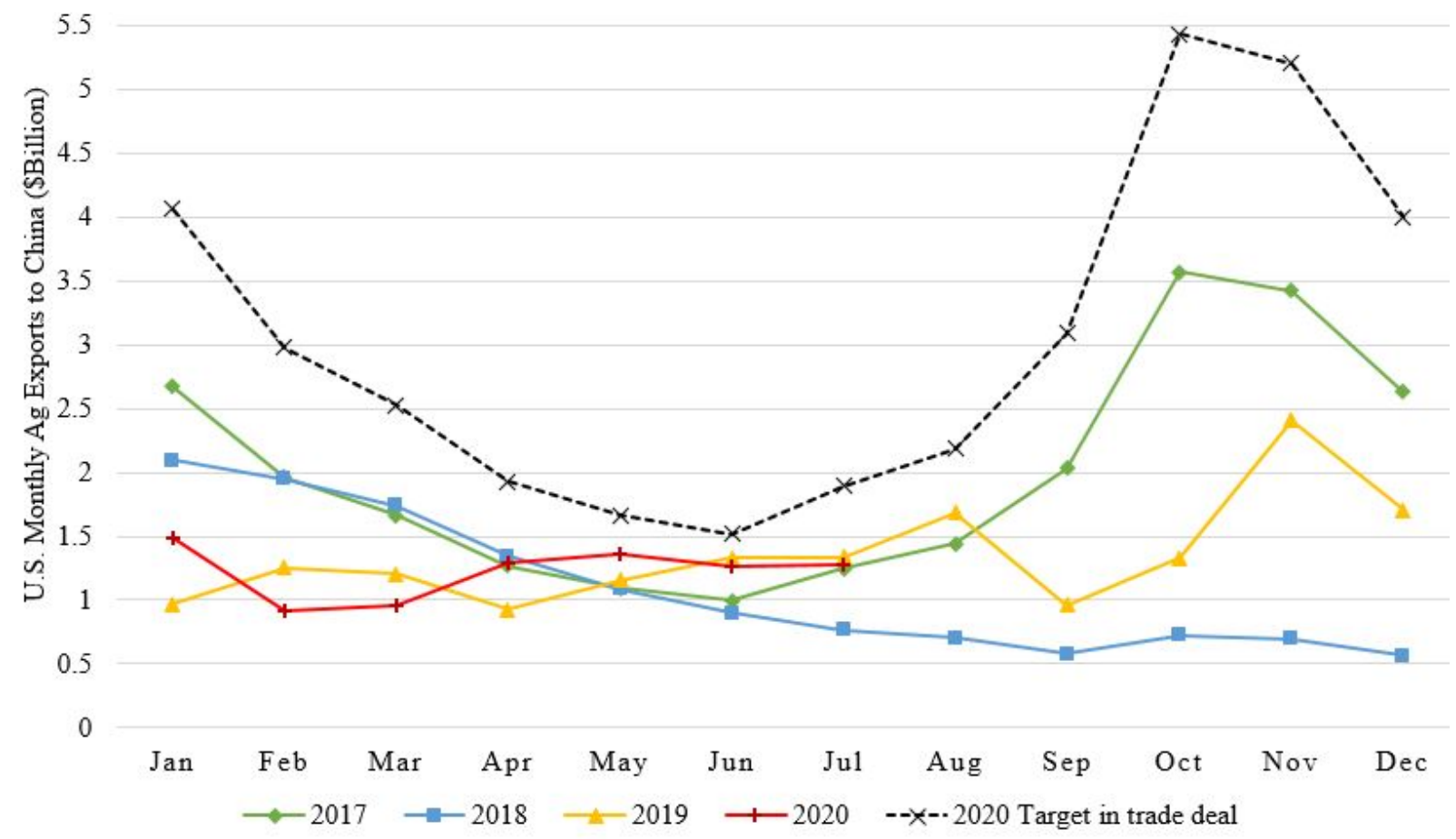

Figure 1: Monthly U.S. agricultural and related products exports to China, 2017--2020 Note: I prorate targets (dashed line) to a monthly basis for illustrative purposes only. The trade agreement does not indicate specific monthly or quarterly targets, only year-end targets. The data source is USDA Foreign Agricultural Service [USDA, 2020b] 
Table 1: China's Predicted Agricultural Imports of Key Commodities from February 15, 2020, to February 14, 2021

\begin{tabular}{|c|c|c|c|c|}
\hline & \multicolumn{2}{|c|}{ Chinese Imports from US } & \multicolumn{2}{|c|}{ Chinese Imports from all sources } \\
\hline & Value (\$Million) & Quantity (Thousand MT) & Value (\$Million) & Quantity (Thousand MT) \\
\hline Corn & 1,262 & 10,091 & 1,992 & 12,984 \\
\hline Soybeans & 9,088 & 28,010 & 36,251 & 94,083 \\
\hline Cotton & 1,443 & 3,973 & 1,986 & 1,243 \\
\hline Sorghum & 1,255 & 6,721 & 1,296 & 6,730 \\
\hline Wheat & 244 & 1,002 & 1,620 & 5,652 \\
\hline Pork & 1,999 & 833 & 11,215 & 4,289 \\
\hline Beef & 142 & 17 & 9,129 & 1,810 \\
\hline Poultry & 369 & 265 & 2,881 & 1,197 \\
\hline Ethanol & 15 & 196 & 48 & 694 \\
\hline Other products & 5,818 & & 132,009 & \\
\hline $\begin{array}{ll}\text { Total agricultural } \\
\text { products }\end{array}$ & 21,635 & & 198,427 & \\
\hline
\end{tabular}

Note: Author's estimation based on 2017 seasonal patterns and China's most recent agricultural purchases from the United States, which includes advanced corn and soybeans sales until August 31, 2020. We assume the advanced corn and soybean sales until August 31 would be delivered in the first year of the trade deal [He et al. [2020a]. 
Table 2: China's Significance in U.S. Agricultural Exports Before and During COVID-19

\begin{tabular}{|c|c|c|c|c|c|c|c|c|c|c|}
\hline \multirow[b]{2}{*}{ Product } & \multicolumn{5}{|c|}{ Total U.S. Exports (\$ Million) } & \multicolumn{5}{|c|}{ U.S. Exports to China ( $\$$ Million) } \\
\hline & 2017 & 2018 & 2019 & Jan-Jul 17 & Jan-Jul 20 & 2017 & 2018 & 2019 & Jan-Jul 17 & Jan-Jul 20 \\
\hline $\begin{array}{l}\text { Agricultural \& Related } \\
\text { Products }\end{array}$ & 157555 & 159176 & 153825 & 88609 & 84660 & 23997 & 13155 & 16277 & 10901 & 8559 \\
\hline Agricultural Products & 138183 & 139544 & 136650 & 78153 & 75921 & 19476 & 9145 & 13860 & 8539 & 7198 \\
\hline Beef \& Beef Products & 7263 & 8357 & 8094 & 3967 & 4277 & 31 & 61 & 86 & 1 & 69 \\
\hline Corn & 9131 & 12462 & 7651 & 6429 & 5456 & 142 & 50 & 55 & 127 & 131 \\
\hline Cotton & 5845 & 6562 & 6148 & 4265 & 3850 & 978 & 925 & 706 & 640 & 847 \\
\hline Distillers Grains & 1851 & 2456 & 2230 & 1057 & 1293 & 62 & 41 & 36 & 52 & 15 \\
\hline Ethanol (non-bev.) & 2412 & 2663 & 2349 & 1428 & 1405 & 83 & 82 & 0 & 0 & 0 \\
\hline Fish Products & 5394 & 5233 & 4857 & 2509 & 2075 & 1232 & 1053 & 822 & 566 & 389 \\
\hline Forest Products & 9525 & 9600 & 8046 & 5436 & 4264 & 3193 & 2857 & 1577 & 1789 & 960 \\
\hline Hay & 1245 & 1222 & 1328 & 735 & 845 & 340 & 272 & 291 & 213 & 240 \\
\hline Pork \& Pork Products & 6485 & 6403 & 6952 & 3698 & 4598 & 662 & 571 & 1300 & 404 & 1509 \\
\hline Soybeans & 21456 & 17058 & 18663 & 9021 & 6804 & 12224 & 3119 & 8005 & 4033 & 1520 \\
\hline Wheat & 6058 & 5387 & 6232 & 3872 & 3630 & 351 & 106 & 56 & 269 & 166 \\
\hline
\end{tabular}

Panel B: Percentage Change in U.S. Agricultural Exports by Commodity from Jan-Jul 2017 to Jan-Jul 2020

\begin{tabular}{|c|c|c|c|c|c|c|c|c|c|}
\hline Product & $\begin{array}{l}\text { World } \\
\text { Total }\end{array}$ & ASEAN & Canada & China & Europe & Japan & $\begin{array}{l}\text { South } \\
\text { Korea }\end{array}$ & Mexico & $\begin{array}{l}\text { US FTA } \\
\text { Partners }\end{array}$ \\
\hline $\begin{array}{l}\text { Agricultural \& Related } \\
\text { Products }\end{array}$ & $-4 \%$ & $15 \%$ & $-1 \%$ & $-21 \%$ & $-9 \%$ & $-4 \%$ & $6 \%$ & $-5 \%$ & $0 \%$ \\
\hline Agricultural Products & $-3 \%$ & $17 \%$ & $0 \%$ & $-16 \%$ & $-12 \%$ & $-2 \%$ & $6 \%$ & $-5 \%$ & $1 \%$ \\
\hline Beef \& Beef Products & $8 \%$ & $13 \%$ & $-7 \%$ & $5036 \%$ & $-46 \%$ & $8 \%$ & $58 \%$ & $-19 \%$ & $12 \%$ \\
\hline Corn & $-15 \%$ & $-11 \%$ & $207 \%$ & $3 \%$ & $-100 \%$ & $-17 \%$ & $-28 \%$ & $4 \%$ & $-3 \%$ \\
\hline Cotton & $-10 \%$ & $-10 \%$ & $-65 \%$ & $32 \%$ & $-24 \%$ & $-36 \%$ & $-47 \%$ & $-67 \%$ & $-50 \%$ \\
\hline Distillers Grains & $22 \%$ & $198 \%$ & $-47 \%$ & $-72 \%$ & $-50 \%$ & $38 \%$ & $71 \%$ & $6 \%$ & $13 \%$ \\
\hline Ethanol (non-bev.) & $-2 \%$ & $-46 \%$ & $-17 \%$ & $100 \%$ & $379 \%$ & $971 \%$ & $94 \%$ & $177 \%$ & $4 \%$ \\
\hline Fish Products & $-17 \%$ & $-13 \%$ & $-6 \%$ & $-31 \%$ & $-11 \%$ & $-30 \%$ & $0 \%$ & $4 \%$ & $-4 \%$ \\
\hline Forest Products & $-22 \%$ & $0 \%$ & $-9 \%$ & $-46 \%$ & $10 \%$ & $-10 \%$ & $-41 \%$ & $-24 \%$ & $-16 \%$ \\
\hline Hay & $15 \%$ & $19 \%$ & $39 \%$ & $12 \%$ & $19 \%$ & $24 \%$ & $-1 \%$ & $-58 \%$ & $6 \%$ \\
\hline Pork \& Pork Products & $24 \%$ & $31 \%$ & $4 \%$ & $273 \%$ & $1 \%$ & $1 \%$ & $5 \%$ & $-27 \%$ & $-5 \%$ \\
\hline Soybeans & $-25 \%$ & $4 \%$ & $-60 \%$ & $-62 \%$ & $-39 \%$ & $1 \%$ & $-33 \%$ & $12 \%$ & $4 \%$ \\
\hline Wheat & $-6 \%$ & $53 \%$ & $144 \%$ & $-38 \%$ & $121 \%$ & $-11 \%$ & $-5 \%$ & $-23 \%$ & $-23 \%$ \\
\hline
\end{tabular}




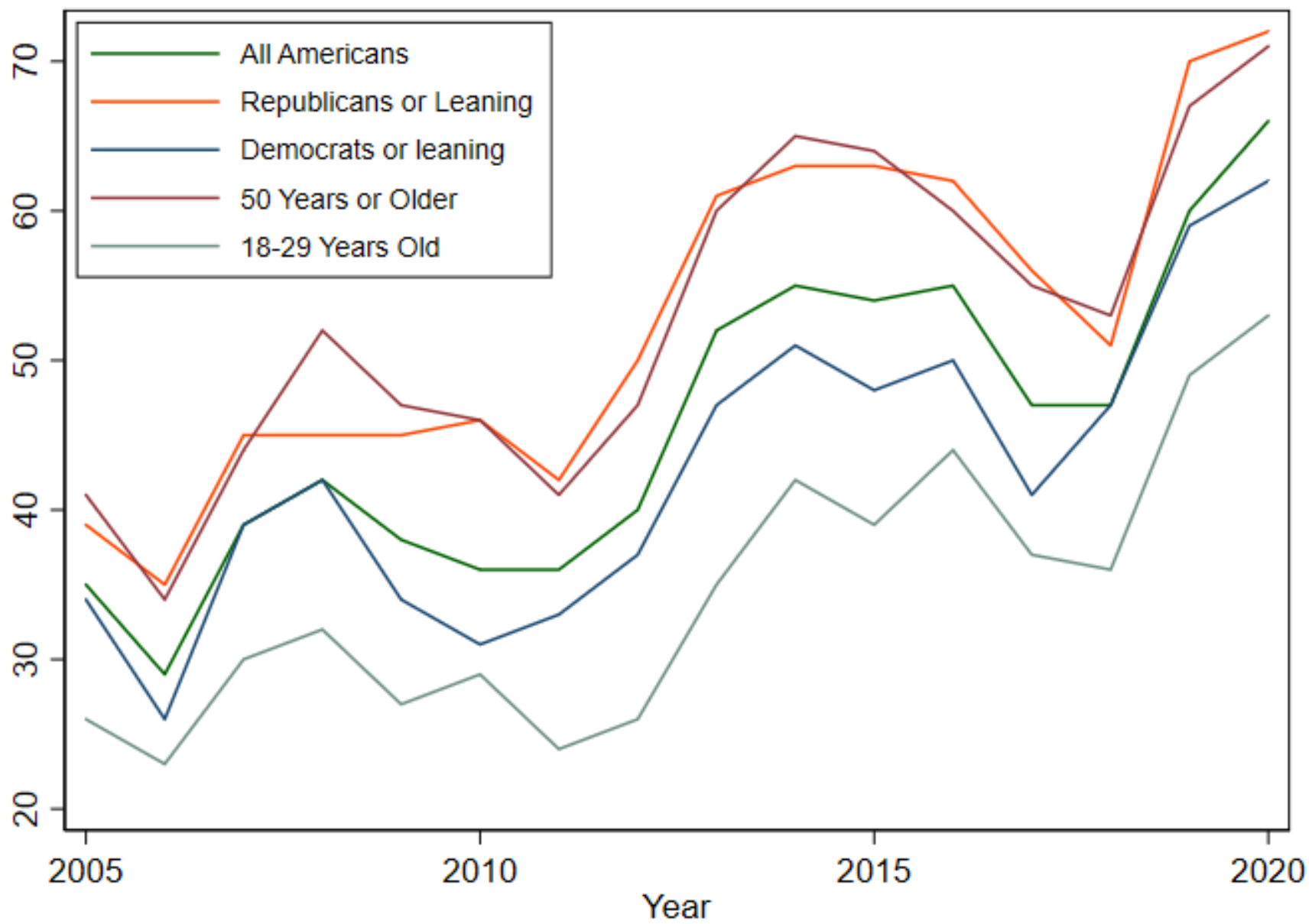

Figure 2: Percent of U.S. Adults Who Say They Have an Unfavorable Opinion of China. Source: Pew Research Center Devlin et al., 2020 


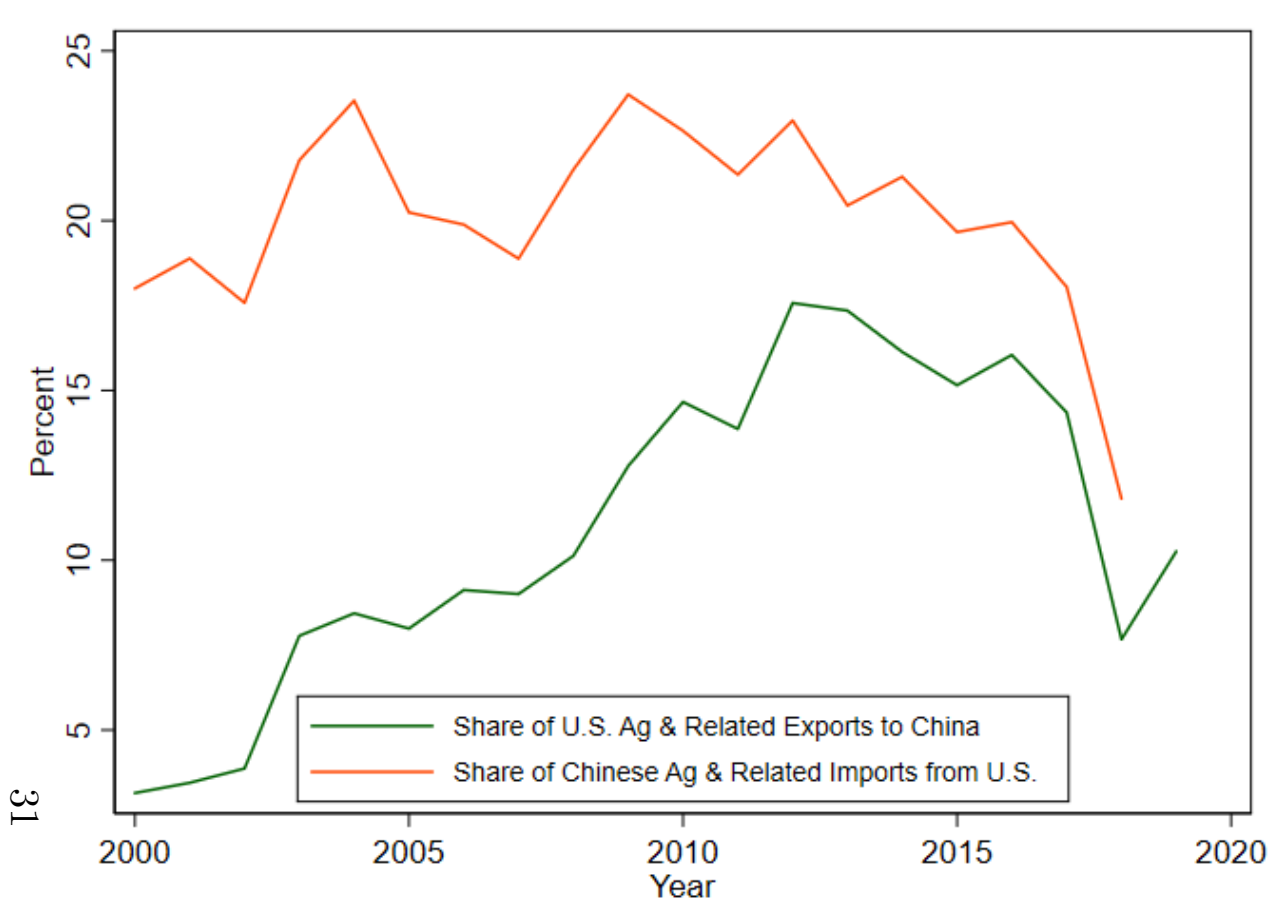

(a) Significance of U.S.-China agricultural trade

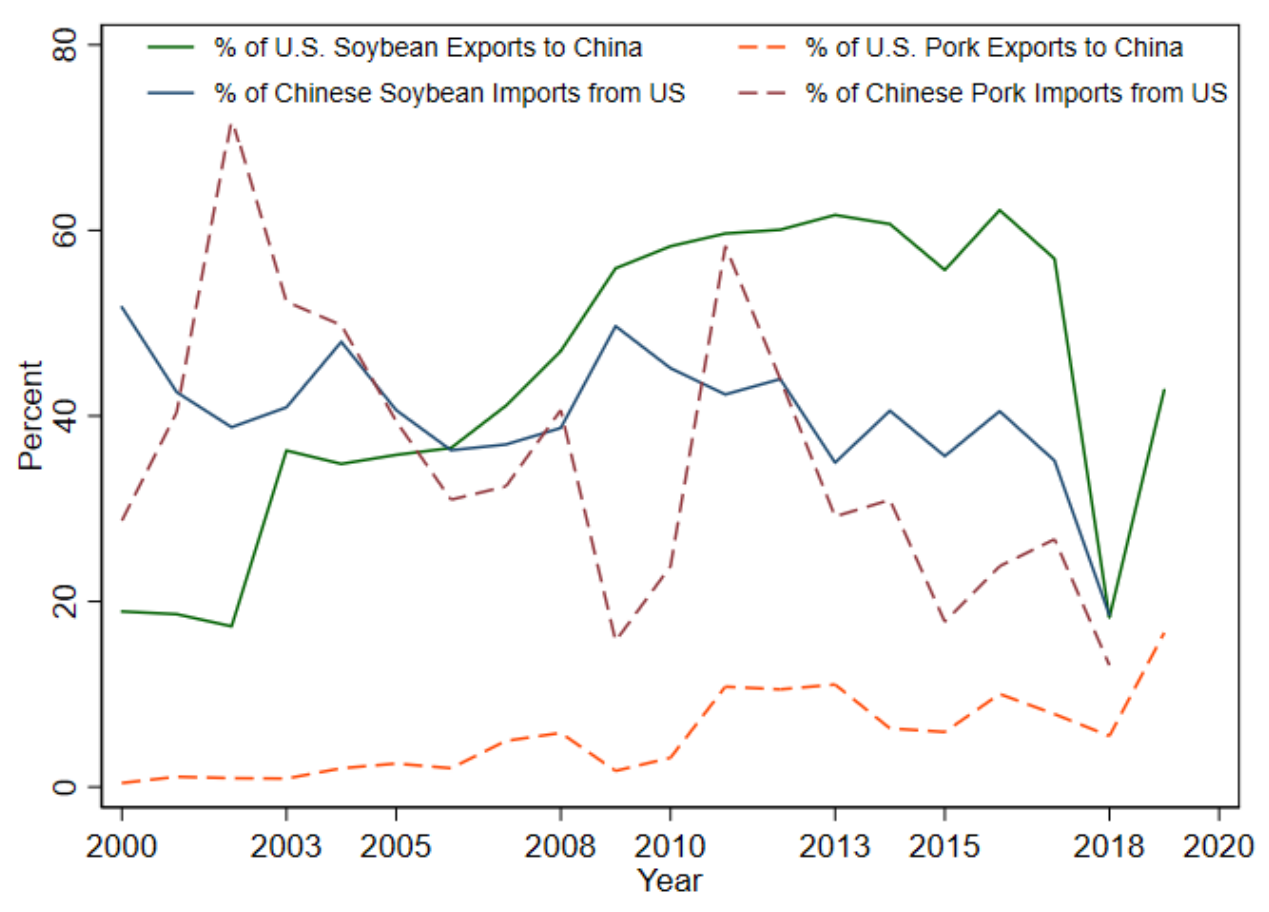

(b) Significance of U.S.-China pork and soybean trade

Figure 3: China's Continued Diversification Away from U.S. in Agricultural Imports, 2000-2019

Source: USDA Foreign Agricultural Service Global Agricultural Trade System (GATS) USDA. 2020b]. 
Table 3: U.S. Midwest Farmers' Perceptions of U.S.-China Trade War and Economic Relations, Spring 2019

\begin{tabular}{|c|c|c|c|c|c|}
\hline & $\begin{array}{l}\text { Strongly } \\
\text { Disagree }\end{array}$ & Disagree & $\begin{array}{l}\text { Neither agree } \\
\text { nor disagree }\end{array}$ & Agree & $\begin{array}{l}\text { Strongly } \\
\text { agree }\end{array}$ \\
\hline \multicolumn{6}{|l|}{ U.S.-China Agricultural Trade } \\
\hline Nothing good will come out of this trade disruption. & 15.9 & 38.7 & 15.5 & 17.2 & 12.7 \\
\hline I hope this trade disruption is resolved soon. & 1.5 & 2.3 & 14.6 & 34.2 & 47.3 \\
\hline $\begin{array}{l}\text { The trade disruption will make U.S. agriculture lose markets to our com- } \\
\text { petitors. }\end{array}$ & 5.1 & 14.7 & 17.8 & 33.5 & 28.9 \\
\hline $\begin{array}{l}\text { The U.S. economy will suffer more than China's economy due to this trade } \\
\text { disruption. }\end{array}$ & 11.8 & 26.8 & 25.2 & 23 & 13.3 \\
\hline $\begin{array}{l}\text { American farmers will bear the brunt of the tariffs imposed by the Chinese } \\
\text { government. }\end{array}$ & 3.4 & 5.6 & 15.1 & 41.6 & 34.3 \\
\hline $\begin{array}{l}\text { The tariffs imposed by the U.S. and China on each other's products will } \\
\text { have long-term negative effects on U.S. agriculture. }\end{array}$ & 6.8 & 20.8 & 25.1 & 27.9 & 19.5 \\
\hline \multicolumn{6}{|l|}{ U.S.-China Economic Relation } \\
\hline $\begin{array}{l}\text { This trade disruption will enhance the economic relationship between the } \\
\text { U.S. and China in the long run. }\end{array}$ & 14.3 & 19 & 30.2 & 31.4 & 5.2 \\
\hline The amount of U.S. debt held by China is a serious problem for the U.S. & 0.9 & 3.8 & 17.6 & 53 & 24.8 \\
\hline The trade deficit with China is harmful to the U.S. economy. & 2.1 & 9.3 & 16.2 & 54 & 18.3 \\
\hline China engages in cyber economic espionage against the U.S. & 1.1 & 1.4 & 27 & 43.2 & 27.3 \\
\hline The number of jobs Americans lose to China is problematic. & 1.6 & 8.4 & 26.4 & 48.9 & 14.9 \\
\hline Economically, China is an ally of the U.S. & 7.8 & 25.1 & 35.9 & 28.2 & 3 \\
\hline $\begin{array}{l}\text { It is important for the U.S. to maintain a healthy economic relationship } \\
\text { with China. }\end{array}$ & 0.1 & 0.6 & 7.2 & 67 & 25.1 \\
\hline China's growing economic strength is good for the world. & 3.4 & 16.6 & 38.6 & 38.1 & 3.3 \\
\hline $\begin{array}{l}\text { The Chinese government exerts too much influence on the value of its cur- } \\
\text { rency. }\end{array}$ & 0.6 & 2.3 & 38.5 & 45.2 & 13.5 \\
\hline $\begin{array}{l}\text { China's record of enforcing intellectual property rights leaves much to be } \\
\text { desired. }\end{array}$ & 0.3 & 1 & 23.3 & 44.5 & 31 \\
\hline
\end{tabular}

Adapted from Qu et al. 2019]. 
Over the next 5 years, do you think U.S. agricultural exports will increase, decrease or remain about the

same

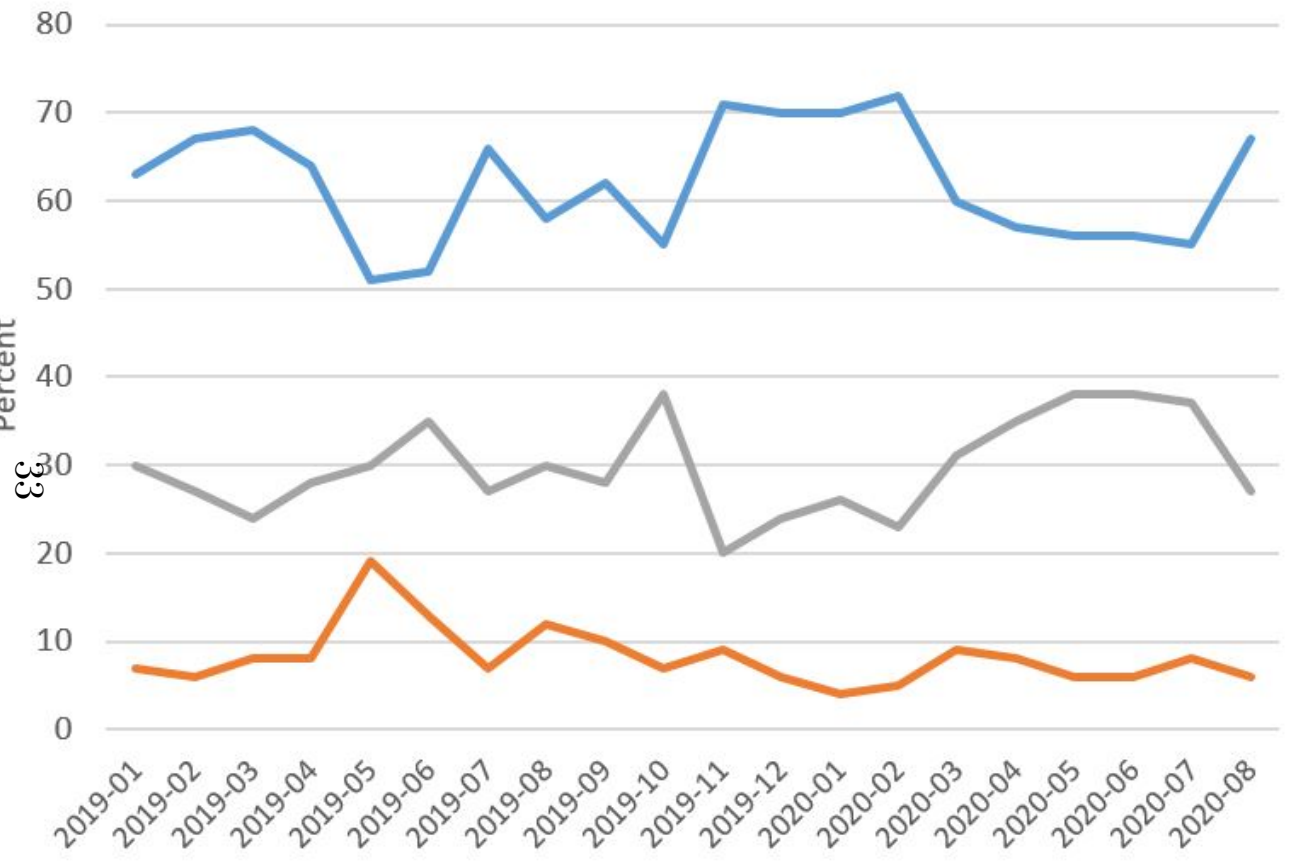

- Increase Decrease Remain about the same
U.S. Agricultural Producers' Perceptions about U.S. China Trade Dispute

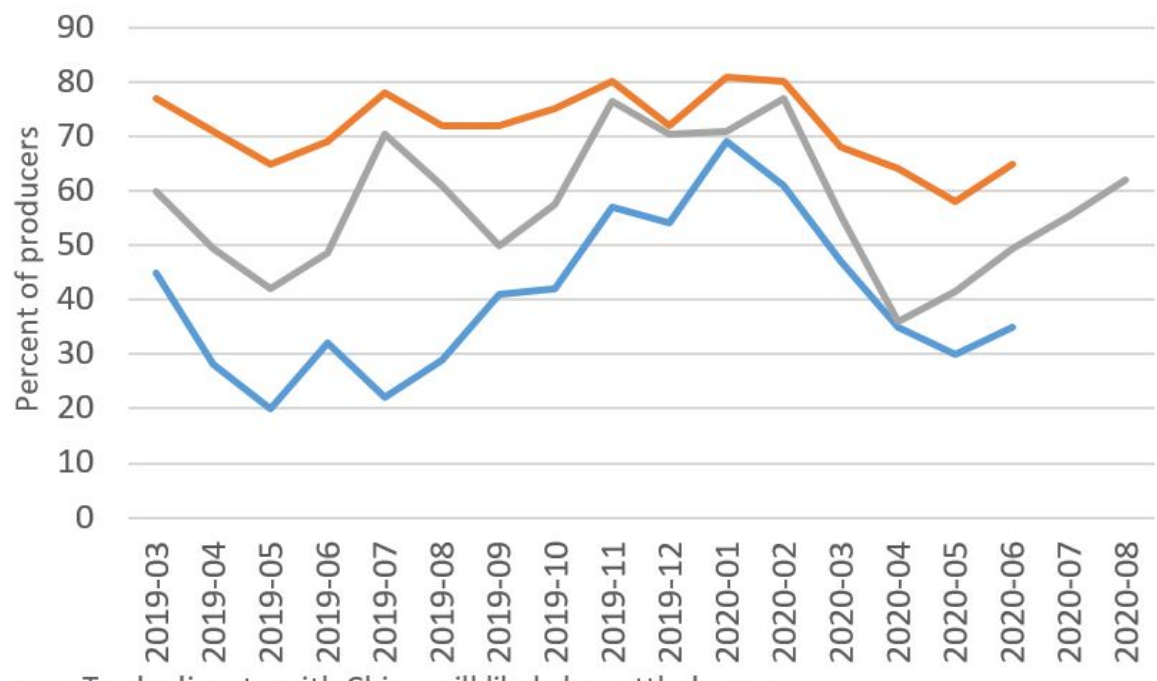

—Trade dispute with China will likely be settled soon

-Trade dispute with China will ultimately be resolved in a way that benefits US agriculture —Index of current conditions

(b) Views about U.S.-China trade dispute resolution

(a) Views of U.S. Ag Exports 5 Years Later

Figure 4: Producers' Views about U.S.-China Agricultural Trade from Ag Economy Barometer, 2019-2020 Source: Ag Economy Barometer led by Purdue University and CME Group [Purdue University. 2020]. 